УДК $32+316.32$

https://doi.org/10.34142/24130060.2020.20.1.14

\title{
РИЗИК ЯК ПРОВІДНА ХАРАКТЕРИСТИКА СУЧАСНОГО СУСПІЛЬСТВА
}

\section{I. І. Пелішенко}

Харківський національний педагогічний університет імені Г.С. Сковороди

У контексті змін, щуо відбуваються в сучасному світі, пропонується розглядати ризик як одну з провідних характеристик сучасного суспільства («суспільства ризику», «індивідуалізованого суспільства»).

Для уточнення змісту циих нових умов розвитку суспільства акиент робиться на теоретичних викладках У. Бека, Е. Гідденса та Н. Лумана.

В якості найбільш адекватного предмета дослідження, щзо відображає всі найбільш істотні ознаки иъього соціально-політичного феномена сучасності, пропонується аналізувати свідомість, структуру і поведінку нового типу особистості так званого «homoriscus». homoriscus.

Ключові слова: ризик, суспільство ризику, індивідуалізоване суспільство,

\section{РИСК КАК ВЕДУЩАЯ ХАРАКТЕРИСТИКА СОВРЕМЕННОГО ОБЩЕСТВА}

\section{И. И. Пелишенко}

В контексте изменений, происходящих в современном мире, предлагается рассматривать риск как одну из ведущуих характеристик современного общества («общества риска», «индивидуализированного общество»).

Для уточнения содержания этих новых условий развития общества акцент делается на теоретических выкладках У. Бека, Э. Гидденса и Н. Лумана.

В качестве наиболее адекватного предмета исследования, отражающего все наиболее существенные признаки этого социально-политического феномена современности, предлагается анализировать сознание, структуру и поведение нового типа личности - так называемого «hотогіsсиs». homoriscus.

Ключевые слова: риск, общество риска, индивидуализированное общество,

\section{RISK AS A LEADING CHARACTERISTIC OF MODERN SOCIETY}

\section{Pelyshenko}

In the context of changes taking place in the modern world, it is proposed to consider risk as one of the leading characteristics of modern society («risk society», «individualized society»).

To clarify the content of these new conditions for the development of society, emphasis is placed on the theoretical calculations of well-known Western social researchers. According to which, a new type of society is characterized by: the disappearance of classes, but the persistence of social inequality; increased overall risks; a change in value orientations (the 
transition from family ethics to personal ethics based on the principle of «obligations towards oneself»; the attractiveness of the idea of social mobility disappears; inequality is transferred to the area of individualization of social risks; an increase in the level of orientation toward individual success; replacement of class conflicts by social clashes that arise on the basis of «innate» signs - race, color, ethnicity, age, bodily disabilities, gender, the emergence of a new social structure that depends on propaganda; the emergence of a coalition with protest moods and actions in various situations.

As the most adequate subject of research, which reflects all the most significant features of this socio-political phenomenon of our time, it is proposed to analyze the consciousness, structure and behavior of a new type of personality - the so-called «homoriscus».

It is proved that the need to take risky, situational decisions encourages «homoriscus» to integrate into the general cultural identity of the so-called «modular person», synthesizing the so-called «super situational» identity. The modern modular person is both an egalitarian and individualistic person, has the ability to unite with fellow citizens, to confront the state and solve extraordinary problems.He is able to move in society, is similar to other representatives of his culture and can fulfill any role laid down in the normative foundation. A «super situational» identity is an identity that synthesizes various forms and types of identity that overlap, take on a new form, and contribute to solving pressing problems.

Key words: risk, risk society, individualized society, homoriscus.

Постановка проблеми. Невизначеність, нестабільність та соціальні ризики стали характерною ознакою XXI ст. Різкі політичні, соціальні, економічні зміни перебудовують реальність. Сучасне суспільство породжує нові види ризиків, які несуть небезпеку соціальної дестабілізації, мають негативні соціальні наслідки для життєдіяльності індивіда, соціальних груп, соціуму в цілому. ««Колонізація майбутнього», - зазначає Р. Роуз, породжує нові види ризиків, інституційно організованих, що впливають на кожну людину. Існування державних організацій не свідчить про те, що товари будуть вироблятися, а неефективність дієвості формальних організацій є застереженням того, що вони не будуть функціонувати зі швидкістю машини-автомата» (Rouz, 2002, s. 32).

Зростає актуальність рефлексії сучасних соціально-політичних процесів в контексті поширення ризику. Категорія «ризику» починає займати почесне місце серед базових категорій системи соціально-політичного знання, таких як «суспільство», «політична система», «політичний інститут», «соціально-класова структура», «політична участь», «політична мобільність» та iн. 
Аналіз актуальних досліджень. У працях таких західних дослідників як У. Бек, П. Бергер, Н. Луман, А. Шюц, І. Гофман, П. Бурдьє, Е. Гідденс, 3. Бауман міститься аналіз щодо певних змін соціальних практик i повсякденності, відображаються суперечності індивідуалізації соціальних практик, досліджуються індивідуальна та групова активність у повсякденній реальності, зміни у життєвих стратегіях тощо у контексті існування саме феномену ризику.

Мета статті - у контексті аналізу теоретичних i емпіричних досліджень ризику розглянути його як провідну характеристику сучасного суспільства.

Виклад основного матеріалу. Суспільство ризику У.Бека стає сучасністю. Остання, як випливає 3 футуристичних прогнозів У.Бека, М. Фуко, Ф. Фукуями вже продукує нові соціальні, економічні, політичні, культурологічні виклики не тільки в теорії, а й на практиці.

Сучасні ризики відрізняються від ризиків традиційного суспільства. Якщо в класичному індустріальному суспільстві суб’єктом соціального та політичного життя були робочій клас та профспілки, то в суспільстві ризику такими суб’єктами стають індивіди. «Індивід створює «рухливу ударну хвилю відповідності», що вгамовує непередбачені події, співвідносить їх 3 ризиком та потенційними загрозами» (Giddens, 1994, s. 122).

А. Вілдавські вважає, що сучасний індивід $є$ активним організатором свого сприйняття, що фіксується в різних його формах. Сучасні ризики руйнують безпеку індивіда, тому він змушений звертатись до експертів, оволодівати новими знаннями про можливість нових викликів та ризиків. Ризик усвідомлюється в момент співвідношення вже набутих знань та знань про нові загрози. Ризик може приходити в життя сучасної людини як нове знання, типологізація нового, що конструює повсякденність. Ризик є вираженням зворотної реакції суб’єкта на кризи конструювання індивідуальної повсякденної реальності. 
Аналізуючи сучасні виклики та загрози, У. Бек робить низку важливих висновків щодо змісту цієї соціально-політичної реальності:

1) класи зникають, але соціальна нерівність залишається;

2) зростають загальні ризики;

3) змінюються ціннісні орієнтації (перехід від сімейної етики до особистісної етики, заснованої на принципі «обов’язків по відношенню до самого себе»;

4) втрачає привабливість ідея соціальної мобільності;

5) «нерівність не зникає, а переноситься у галузь індивідуалізації соціальних ризиків»;

6) «зростає значення орієнтації на індивідуальний успіх»;

7) на зміну класовим конфліктам приходять конфлікти на основі «вроджених» ознак: раси, кольору шкіри, етнічної приналежності, віку, тілесних вад, статі;

8) виникає нова соціальна структура, залежна від пропаганди;

9) виникають коаліції з протестними настроями і діями в різних ситуаціях (Stepanova, 2017, s. 104).

У контексті виникнення нових загроз, сучасна людина стикається 3 новими ризиками, тому концепт «суспільства ризику» описує і повсякденне життя людини. Індивідуальна свідомість та життєвий досвід, з одного боку, дозволяють орієнтуватись у ризикогенному середовищі, але виникають нові ризики: втрата ідентичності, самотність, стандартизація індивідуальності.

Н. Луман стверджував, що ризик стає реальним лише у зв’язку 3 прийнятим рішенням індивідом або суспільством. Ризик $є$ не тільки параметром соціальної ситуації, але й фактором, що конструює ситуацію. Суб’єктами ризику стають всі актори соціального життя: індивіди, соціальні групи, організації, соціальні інститути, суспільство в цілому. Об'єктами ризику є індивіди або соціальні групи, які на собі відчувають наслідки рішень, прийнятих іншими. Суб’єкти є одночасно і об’єктами, тому що на собі відчувають наслідки, прийнятих ними рішень, тому за об’єктивно- 
суб’єктивними якостями характеризують індивідуальні та колективні форми ризику.

Загрози суспільства ризику починають загрожувати не тільки індивіду, але і суспільству в цілому. У сучасному суспільстві кожне рішення впливає на виникнення ризику, відмова від рішення теж призводить до ризику. прийняте рішення спричиняє ризиковані наслідки, що призводять до подальших ризиків, які в свою чергу викликають нові ризики. Складається «дерево рішень» за Н. Луманом, що акумулює нові ризики. Н. Луман називає ризик соціальною проблемою, де діяльність особистості залежить від запитів соціального оточення і суспільства, тому ризикована поведінка не підпадає під схему «раціонального/ірраціонального», за прийнятими рішеннями завжди слідують нові ризики.

3 цього випливає, що одним із очевидних результатів виникнення та існування в суспільстві нових видів ризику є зміни у свідомості та поведінці акторів суспільно-політичного життя, тобто, формування нового типу особистості - так званого «homoriscus».

Суспільство ризику стає реальністю у глобальному вимірі, тому визначення homoriscus стає предметом ідентифікації сучасної людини, що дозволяє визначити свої ролі та статуси в суспільстві, дозволяє створити інституційні засади своєї діяльності. Визначення моделі «homoriscus, iii детальний аналіз, дозволяє регулювати соціальні відносини, наближує до фіксації змін у структурі особистості. Усвідомлення невідворотності ризиків у повсякденному житті визначає нові норми поведінки людини, ризик стає виховним та освітнім моментом. Н. Луман зазначав, що вільної від ризику поведінки не може бути в принципі, тому homoriscus поступово вбудовується у структуру особистості.

Необхідність прийняття ризикованих, ситуаційних рішень спонукає homoriscus вбудовуватись у загальнокультурну ідентичність так званої «модульної людини», синтезуючи так звану «надситуаційну» ідентичність. 
На думку Е. Геллнера (одного із фундаторів теорії модульної людини) модульна людина - це ознака сучасності, вона вже з'явилась, завдяки ій стало можливим громадянське суспільство. «Відповідаючи на питання, яким чином можуть існувати інститути і асоціації, що мають врівноважити державу та не скують по рукам і ногам членів суспільства, - стверджує дослідник, - ми повинні відповісти: це можливо головним чином завдяки модульності людини» (Gellner, 2004, s. 119).

Крім того, Е. Геллнер вважає, що «відсутність модульності виключає можливість вибору технології за принципом ефективності, замість цього будь-яку людську діяльність змушені розглядати з урахуванням багатьох невловимих занадто складних відносин, що пов'язують іiі з органічним, неподільним культурним цілим» (Gellner, 2004, s. 118).

Сучасна модульна людина $\epsilon$ одночасно егалітаристичною i індивідуалістичною, має здатність об’єднуватись 3 співгромадянами, протистояти державі та вирішувати надзвичайні завдання. Вона здатна переміщуватися в суспільстві, не тільки тому що схожа на інших представників своєї культури і може виконувати будь яку роль, закладену у нормативному фундаменті. Напроти, вона готова до будь яких змін у своїх заняттях та в своїй діяльності. Ї̈і модульність - це здатність в рамках визначеного культурного поля вирішувати різні задачі. Якщо знадобиться, в iï розпорядженні завжди є посібники та книги, що дозволять їй засвоїти будь яке діло (Gellner, 2004, s. 121).

Суспільство ризику збільшує кількість важливих соціальних орієнтирів для особистості, розділяє соціальну ідентичність на частини, які по черзі стають актуальними. Соціальна ідентичність особистості стає одним 3 головних факторів розвитку суспільства, вона ілюструє соціальні зміни. Соціальні інститути і відносини, рольові функції в публічній сфері, співвіднесення себе 3 загальнозначущими культурними орієнтирами, сукупність уявлень про своє місце в суспільстві, цінності та поведінкові моделі - головні характеристики соціальної ідентичності сучасної людини. 
Криза соціальної ідентичності вказує на кризові моменти соціальних утворень (сім’ї, професійних груп, партій та держави). Зміни соціальної ідентичності призводять до значних суспільних змін, до зміни самоідентифікації всього суспільства, та свідчать про модернізаційні зміни в суспільстві. Останнім часом формується гібридна ідентичність, яка ситуаційно сприймає модерністські або традиційні цінності. Суспільство ризику буде сприяти поширенню гібридної ідентичності на фоні існування традиційної, посилюючи розрив між поколіннями.

Аналізуючи ці процеси Е.Гідденс стверджував: «реакцією на зростання невизначеності на особистісному рівні стане утвердження особистої індивідуальності шляхом опори на особисто вмотивований вибір як в сфері споживання, в оформленні житла, в організації дозвілля, так і в сфері соціальної поведінки. В розвинутих країнах самоідентифікація буде спиратися на модельні життєві стилі (приклад екологічного споживання, вегітарианства або соціального підприємництва» (Semenenko, Lapkin i Pantin, 2010, s. 54).

Так звана «надситуаційна» ідентичність синтезує різні форми і типи ідентичності, що накладаються одна на одну, складаються у надситуаційну форму, сприяють вирішенню нагальних потреб (Kalashnikova, 2012, s. 16). Ризикогенне середовище формує людей з ситуаційним сприйняттям ризику, невизначеності, швидкою зміною ситуації, нових викликів. Homoriscus здатний до прийняття швидких, неочікуваних рішень, а якості модульної людини дозволять розвивати компетентність, професіоналізм.

Нестабільність та невизначеність вимагають від сучасної людини гнучкості або флексибельності, широкої варіативності, пластичності у використанні робочого часу та політики зайнятості. Глобальна динаміка ризикогенності потребує від людини швидкого пристосовування до існуючих умов. Дестабілізація звичного соціального життя, уразливість сучасної людини вимагають розвивати в собі флексибельность. Разом 3 тим, гнучкість в умовах тотальної політичної, економічної, соціальної невизначеності 
потребує необхідного економічного, соціального та культурного капіталу для протистояння дестабілізуючим обставинам. Флексибельність за умови дестабілізації не завжди дає змогу управляти своїм життям та отримати бажану свободу. Загроза безробіття, страх втратити роботу, перехід на неповний робочий день, нестабільна самозайнятість, перехід на «гнучкий найм» за З. Бауманом розвиває почуття особистісного безсилля, розгубленість, аномію, власну незатребуваність, культурну деструкцію, почуття себе зайвим у суспільстві.

Дослідник В. Лапша пропонує свою типологію homoriscus, кожен елемент якої по-різному реагує на ризики:

перша група характеризується тим, що ii представники спеціально йдуть на ризик для досягнення поставлених задач. Ризикувати вони можуть лише тоді, коли їх психічні якості дозволяють діяти таким чином. Такі особистості йдуть на ризик усвідомлено, порівнюючи та оцінюючи як свої можливості, так і реальність досягнення поставлених задач;

друга група представлена тими членами соціуму, що ризикують для свого задоволення, не маючи на ризик об'єктивних підстав, та насолоджуються процесом. Такі особистості перевіряють судьбу. Вони переоцінюють або недооцінюють свої можливості, занадто впевнені у своїх діях, наражають себе та оточуючих на великі ризики;

третя група характеризується надзвичайною обережністю, а результаті чого втрачають впевненість при екстремальних, конфліктних, критичних ситуаціях. Ці особи уважно обирають варіанти поведінки в ситуації, акцентують увагу на альтернативності варіантів поведінки, за якою ризик мінімальний або відсутній (Lapsha, 2018, s. 22).

Сучасне суспільство породжує нові соціальні ризики, що не вкладаються в «класичну» картину, збільшується впливовість факторів зовнішнього впливу (окремих явищ або сукупності природних, біологічних, медичних, техногенних, соціальних процесів) на окремого індивіда i на суспільство в цілому. Природні, біологічні екосистеми знаходяться під 
впливом діяльності людини, формують блок антропогенних та природних факторів, що загрожують здоров’ю людства. В цих умовах важливу роль грають соціальні фактори епідеміологічного ризику - це умови, викликані діяльністю людей як членів суспільства, що підвищують вірогідність негативного впливу на захворюваність населення. Бідність зазначається у медицині як фактор ризику для багатьох хвороб. Бідність асоціюється 3 недостатнім харчуванням, обмежує можливості для повноцінного відпочинку, знижує доступність медичних послуг, тому бідність теж виступає соціальним ризиком.

У цілому, фактори ризику поділяються на керовані та некеровані, некеровані - це природні сили та явища, пандемії. Керовані фактори ризику такі, ступінь ризику яких може бути знижена за рахунок соціального, економічного, політичного, медичного впливу. Зараз оцінки потребує комплексний вплив факторів ризику, який замінив дію окремого фактору ризику, тобто вже треба аналізувати комплексну оцінку сумарного ризику, яка повинна визначити тактику подолання та профілактики соціальних ризиків як на індивідуальному, так і на загальнодержавному рівнях.

Глобальні ризики трансформуються у індивідуальні. Дистанційна освіта, сурогатне спілкування, «держава в смартфоні», покупки по Інтернету впливають на соціальну ідентичність сучасної людини. Здоров’я та дозвілля стають показниками успіху та самореалізації сучасної людини.

Складна соціальна реальність змушує сучасну людину діяти як сукупність простих модулів, тому свідомість стає теж модульною. В умовах високої ризикогенності суспільства спрощення, ділення на прості модулі сприяє швидкій пристосованості людини до складного соціокультурного простору. Конкретно-практичні моделі поведінки поєднуються 3 емоційнообразними судженнями про реальність. Нестабільність та високі темпи соціальних змін призводять до втрати автономії особистості, разом 3 якою індивід втрачає потребу в соціальній активності, яку модульна людина замінює надіндивідуальною надбудовою. Варіантами надбудови можуть 
стати атрибути успішності сучасної людини: кар’єра, освіта, матеріальний достаток. Сучасні люди перетворюються в каркас, в який вбудовані модулі, тому сучасна людина не належить сама собі, вона є конструкцією, що містить необхідні модулі, які людина вбудовує в залежності від потреб текучої сучасності. Акцент переноситься з самопізнання на самоконструювання, де предметом конструювання стають соціальний статус, статеві відносини, тіло, психіка, сексуальність. Модульна людина вбудовує в свій каркас різні homo, такі як homoriscus та homocuber і стає частиною інформаційного простору, де класичні проблеми моралі замінюються на систему переваг.

Висновки і перспективи подалыших досліджень. В умовах тотальної нестабільності та невизначеності виникають нові ризики сучасності, хід, яких складно спрогнозувати. Збільшується кількість екстраординарних ризиків, що потребують значних матеріальних ресурсів, які перевищують можливості однієї країни. Вирішення нагальних загроз потребує миттєвих, неординарних рішень, насамперед, з боку влади. За цих обставин, перелік модифікованих, нетипових соціальних ризиків та можливих відповідей на них розширюється так, що законодавча база держави не спроможна їх експлікувати. Очевидно, що ризик стає провідною характеристикою сучасного суспільства. Найбільш очевидною формою його фіксації та предметом подальшого дослідження $є$ реальна поведінка індивіда, так званого «homoriscus».

\section{ЛІТЕРАТУРА}

1. Геллнер, Э. 2004. Условия свободы. Гражданское общество и его исторические соперники. Москва: Московская школа политических исследований.

2. Гидденс, Э., 1994. Судьба, риск и безопасность. THESIS, 5, с. 107-134.

3. Калашникова, Е. М., 2012. Идентичность человека в обществе риска. Вестник Вятского государственного университета. Философия и сощиология, 4, с.14-17.

4. Лапша, В. Л., 2018. Риск в сознании социума (общества) и отношение к нему. Философия права, 4 (87), с.20-24.

5. Семененко, И. С., Лапкин, В. В. и Пантин, В. И., 2010. Идентичность в

\section{REFERENCES}

1. Gellner, E. 2004. Usloviya svobody. Grazhdanskoe obshestvo i ego istoricheskie soperniki. Moskva: Moskovskaya shkola politicheskih issledovanij.

2. Giddens, E., 1994. Sudba, risk i bezopasnost. THESIS, 5, s. 107-134.

3. Kalashnikova, E. M., 2012. Identichnost cheloveka V obshestve riska. Vestnik Vyatskogo gosudarstvennogo universiteta. Filosofiya i sociologiya, 4, s.14-17.

4. Lapsha, V. L., 2018. Risk v soznanii sociuma (obshestva) i otnoshenie k nemu. Filosofiya prava, 4 (87), s.20-24.

5. Semenenko, I. S., Lapkin, V. V. i Pantin, V. I., 2010. Identichnost v sisteme koordinat mirovogo razvitiya. Polis. 
системе координат мирового развития.

Полис. Политические исследования, 3, с. 40-59.

6. Роуз, Р., 2002. Достижение целей в квазисовременном обществе: социальные сети в России. $\mathrm{OHC}, 3$, с. 23-38.

7. Степанова, И. Н., 2017. Детерминанты социального поведения в концепции общества риска У. Бека. Вестник КГУ, 1 , c. 100-104.
Politicheskie issledovaniya, 3, s. 40-59.

6. Rouz, R., 2002. Dostizhenie celej v kvazisovremennom obshestve: socialnye seti v Rossii. ONS, 3, s. 23-38.

7. Stepanova, I. N., 2017. Determinanty socialnogo povedeniya v koncepcii obshestva riska U. Beka. Vestnik KGU, 1, s. 100-104.

\section{Інформація про автора}

Пелішенко Ірина Іванівна - кандидат філософських наук, доцент, доцент кафедри політології, соціології і культурології Харківського національного педагогічного університету імені Г.С. Сковороди; e-mail: pelishenkoirina@gmail.com; ORCID: https://orcid.org/0000-0002-4735-9016;

Стаття надійшла до редакції: 26.12.2019 р. $\quad$ Прийнята до друку: 17.12.2019 p. 